Центр воєнно-стратегічних досліджень Національного університету оборони України імені Івана Черняховського, Київ

\title{
Планування розвитку спроможностей ракетних військ і артилерії Збройних Сил України: понятійний апарат
}

Резюме. Здійснено аналіз понятійного апарату планування розвитку спроможностей ракетних військ і артилерії.

Ключові слова: управління, планування, спроможності, бойові можливості, ракетні війська i артилерія.

Постановка проблеми. Метою проведення оборонної реформи в Україні $\epsilon$ набуття та підтримання силами оборони необхідного рівня бойової готовності та здатності до виконання завдань оборони держави (оборонних спроможностей), ефективного реагування на виникаючі воєнні загрози і воєнно-політичні виклики національній безпеці [1].

Досягнення визначеної мети оборонної реформи здійснюється з урахуванням наявних ресурсних обмежень шляхом впровадження в секторі оборони оборонного планування на основі спроможностей i набуття спроможностей, необхідних для гарантованого виконання завдань 3 оборони держави, зокрема i шляхом розвитку спроможностей ракетних військ і артилерії Збройних Сил України (PBiA 3С України).

Аналіз нормативно-правових актів, практичне виконання заходів під час впровадження оборонного планування на основі спроможностей упродовж 2019 року виявило розбіжності у поглядах фахівців, зв'язані 3 відсутністю єдиного бачення понятійного апарату та методології переведення спроможностей у кількісно-якісні показники для переходу ЗС України та інших складових сил оборони до планування на основі спроможностей.

Аналіз останніх досліджень i публікацій, а також сучасних концептуальних документів України [2, 3] показує, що основною рисою воєнних дій залишається домінуюча роль вогневого ураження противника всіма наявними силами $\mathrm{i}$ засобами, яке $\epsilon$ основою будь-якого способу ведення операції (бою, бойових дій) та перетворюється на вирішальний фактор розгрому противника, визначає хід і результат воєнних дій.

PBiA 3С України $\epsilon$ і залишатимуться у майбутньому тим родом військ, який матиме вирішальне значення у нанесенні вогневого ураження противнику для досягнення цілей в операції (бою), тому планування розвитку їх спроможностей є актуальним завданням.

Наявні протиріччя між зростанням обсягу завдань вогневого ураження противника (ВУП) і бойовими можливостей PBiА ЗС України з їх виконання, потребують визначення необхідних спроможностей $\mathrm{PBiA}$ та здійснення якісного планування розвитку РВіА як роду військ.

На сьогодні в рамках оборонного огляду в Україні вирішується завдання щодо планування розвитку $\mathrm{PBiA}$ за процедурами оборонного планування на основі спроможностей, які викладені у Методичних рекомендаціях [4].

Водночас аналіз останніх досліджень свідчить, що зміст процесів планування реформування і розвитку РВіА ЗС України в попередні роки не відповідав реалізації його функцій і як наслідок мета реформування i розвитку $\mathrm{PBiA} \mathrm{3С} \mathrm{України} \mathrm{не} \mathrm{була} \mathrm{досягнута.}$

Аналіз сучасних концептуальних документів з оборонного планування на основі спроможностей показує, що дослідники та фахівці мають декілька поглядів щодо сутності поняття “спроможність" та його взаємозв'язку 3 такими поняттями як “здатність та "бойові можливості".

Так, нерозуміння змісту процесу планування, вживання термінів 3 їх неоднозначним визначенням стримуе розвиток методологічних основ стратегічного планування в секторі безпеки і оборони та може привести до негативних наслідків.

Отже, нинішній стан вказує на необхідність удосконалення та впровадження понятійно-категорійного апарату у сфері оборони.

Метою статті є надання єдиного визначення поняттю “планування розвитку 
спроможностей ракетних військ і артилерії Збройних Сил України.

\section{Виклад основного матеріалу.}

Введення у розгляд будь-якого поняття $\epsilon$ процес його визначення, тобто роз'яснення змісту та визначення для розпізнавання об'єкта (предмета), що позначається цим терміном серед інших об'єктів (предметів), які досліджуються.

До того ж слід ураховувати.

По-перше, таке визначення доцільно здійснювати за допомогою застосування найбільш поширеного методу, що засновується на логічному відношенні “pid вид", тобто через ознаки родового поняття та видові відмінності [5].

По-друге, виникає необхідність у застосуванні сукупності таких вихідних i допоміжних понять, як “спроможність", “розвиток”, “планування” та “управління". Поняття "планування розвитку спроможностей ракетних військ і артилерії Збройних Сил України" буде похідним. Загалом означені поняття утворюватимуть несуперечливу логічну систему.

По-третє, під час визначення поняття “планування розвитку спроможностей ракетних військ і артилерії Збройних Сил України" орієнтуватимемося на надання більш точного визначення, такого, за допомогою якого можна встановити методи дослідження предмета, що позначається однойменним терміном [6]. Проте слід підкреслити, що такі визначення $є$ більш широкими, внаслідок необхідності посилання на суттєві ознаки понять, що встановлюють їх обсяг і зміст.

PBiA $\epsilon$ окремим родом військ, який призначений для ураження живої сили, танків, артилерії, протитанкових засобів противника, авіації, об'єктів ППО та інших важливих об'єктів під час ведення загальновійськової операції (бою).

До складу РВіА ЗС України входять органи управління $\mathrm{PBiA}$, бойові військові частини та частини (установи) забезпечення. Покладені на них функції сприяють якісному виконанню завдань, які стоять перед цим родом військ, а саме здійснення ВУП в операціях.

Зважаючи, що “система - це сукупність елементів (об'єктів (суб'єктів) будь-якої природи), які знаходяться в певних відносинах i зв'язках одним 3 одним i сумісним функціонуванням забезпечують розв'язання конкретної проблеми [7], PBiA ЗС України необхідно розглядати як складну організаційно-технічну систему, що складається 3 ієрархій взаємозв'язаних і взаємодіючих між собою i зовнішнім середовищем систем мінімального рівня ієрархій, які складаються 3 множини підсистем.

Зі свого боку, РВіА ЗС України $\epsilon$ підсистемою системи більш вищого рівня ЗС України.

Відображення PBiA ЗС України як складної організаційно-технічної системи створює передумови для встановлення іiі зв'язку з поняттям “спроможності.

Міністерство оборони США запровадило універсальне визначення спроможностей [8], як “здатність по досягненню необхідного результату, визначеного критеріями та умовами за допомогою комбінації сил $i$ засобів, а також методів $i$ способів $\ddot{\ddot{x}}$ застосування для виконання поставлених завдань."

У керівних документах держав-членів HATO [9] спроможності (capabilities) також визначені як "здатність досягати потрібного ефекту при заданих стандартах та умовах на основі комбінації засобів і способів, застосовуваних для вирішення набору завдань."

У Рекомендаціях 3 оборонного планування [4] поняття “спроможність" визначається як "здатність структурної одиниці (елементу) Збройних Сил (сил оборони) або сукупності сил i засобів виконувати певні завдання (забезпечувати реалізацію визначених військових цілей) за певних умов обстановки, ресурсного забезпечення та відповідно до встановлених стандартів".

3 огляду на лінгвістичний аналіз сутності поняття “спроможність" [10, 11] можна виділити його значення, а саме: властивість; здатність до здійснення чогонебудь; можсливість виконання певних дій для отримання результату.

Зважаючи на те, що поняття “спроможність" в оборонному плануванні носить комплексний узагальнюючий характер, оскільки має характеризувати функціонування великої кількості складних організаційнотехнічних систем різного рівня управління, 3 різними цілями, функціями, можливостями i завданнями, існує необхідність виокремлення складових цього поняття, спільних для всіх систем, що дасть змогу більш чітко визначити його фізичний смисл, а надалі дасть змогу обрати (визначити) систему показників i критеріїв оцінки. 
Отже “спроможність" - це властивість, тому це поняття невід’ємне від її носія.

Під носієм спроможності в оборонному плануванні розуміються організаційні структури: з'єднання, військові частини, підрозділи, які можуть об'єднуватись у функціональні структури - угруповання військ.

Водночас, кожна організаційна (функціональна) структура має певні оперативні (бойові) можливості (характеристики) та здатність (готовність) їх реалізувати, використовуючи залежно від умов певні форми i способи застосування, визначені відповідними доктринальними документами (основами застосування, настановами, статутами тощо), для досягнення відповідної мети в операції (бою).

Так, визначення поняття спроможності, як певної властивості має містити (рис. 1): носій спроможності (організаційна, функціональна структура); його оперативні (бойові) можливості (характеристики); доктринально визначені форми і способи застосування;

мету, яку має досягти носій спроможності під час ведення операції (бою).

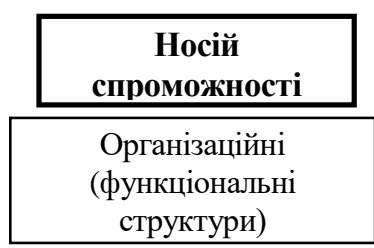

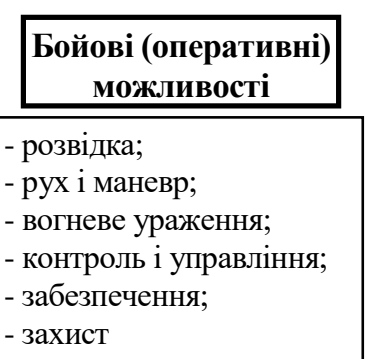

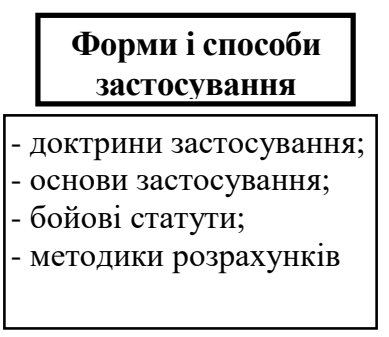

Рис. 1. Складові поняття спроможності

Зважаючи на зазначене, доцільно надати таке визначення: спроможності - це властивість функціональної (організаційної) структури, яка характеризує іiі здатність (готовність) реалізувати власні оперативні (бойові) можливості для досягнення визначеної мети в операції (бою), використовуючи доктринально визначені форми і способи застосування.
Відповідно до проєкту Каталогу наявних спроможностей ЗС України [12], який відпрацьовується за результатами оборонного огляду протягом 2019 року, носіями спроможностей $\mathrm{PBiA} \mathrm{ЗС} \mathrm{України} є$ органи управління $\mathrm{PBiA,} \mathrm{бойові} \mathrm{військові} \mathrm{частини}$ (підрозділи), частини та установи забезпечення (Табл. 1).

Перелік спроможностей і носіїв спроможностей РВіА ЗС України

\begin{tabular}{|c|c|c|c|c|}
\hline \multirow{2}{*}{ № 3/II } & \multicolumn{2}{|r|}{ Спроможність } & \multicolumn{2}{|r|}{ Носій спроможності } \\
\hline & код & назва & код & назва \\
\hline \multirow[t]{6}{*}{1} & \multicolumn{4}{|c|}{ ФГС №2 Забезпечення готовності військ (сил) } \\
\hline & \multicolumn{4}{|c|}{ 1FR-1.4 Наукова і науково-технічна діяльність } \\
\hline & 1FR-1.4.2.15 & $\begin{array}{l}\text { Проведення досліджень } 3 \text { питань розвитку } \\
\text { РВіА ЗС України }\end{array}$ & 2FR-1.4.7.15 & Науково-дослідний центр РВіА \\
\hline & \multicolumn{4}{|c|}{ 1FR-2. Підготовка органів військового управління та військ (сил) ЗС Украӥни } \\
\hline & 1FR-2.3.2.2 & $\begin{array}{l}\text { Розроблення доктринальних документів із } \\
\text { підготовки РВіА ЗС України }\end{array}$ & 2FR-2.2.4.2 & $\begin{array}{l}\text { Управління підготовки РВіА } \\
\text { КСВ, (управління РВіА ОК) }\end{array}$ \\
\hline & 1FR-2.3.5.3 & $\begin{array}{l}\text { Підготовка військових частин (підрозділів) } \\
\text { РВіА 3С України }\end{array}$ & 2FR-2.2.10.3 & $\begin{array}{l}\text { Міжвидовий центр підготовки } \\
\text { РВіА }\end{array}$ \\
\hline \multirow[t]{4}{*}{2} & \multicolumn{4}{|c|}{ ФГС №5 Застосування (ENGAGE - E) } \\
\hline & \multicolumn{4}{|c|}{ 1E-2.2 Вогневе ураження наземними засобами } \\
\hline & \multirow[t]{2}{*}{ 1E-2.2.1 } & \multirow{2}{*}{$\begin{array}{l}\text { Спроможність точно атакувати наземні і підземні } \\
\text { цілі на відстань до } 70(120) \text { км }\end{array}$} & $2 \mathrm{E}-2.3$ & Ракетна бригада \\
\hline & & & $2 \mathrm{E}-2.3 .1$ & Ракетний дивізіон \\
\hline & \multirow{2}{*}{ 1E-2.2.2 } & \multirow{2}{*}{$\begin{array}{l}\text { Спроможність точно атакувати наземні і підземні } \\
\text { цілі на відстань до } 70 \text { км }\end{array}$} & $2 \mathrm{E}-2.4 .1$ & Окремий реактивний полк \\
\hline & & & $2 \mathrm{E}-2.4 .4$ & Реадн 300 мм \\
\hline & \multirow{5}{*}{$1 \mathrm{E}-2.2 .3$} & \multirow{5}{*}{$\begin{array}{l}\text { Спроможність точно атакувати наземні і підземні } \\
\text { цілі на відстань до } 35 \text { км }\end{array}$} & $2 \mathrm{E}-2.4$ & Реактивна артилерійська бригада \\
\hline & & & $2 \mathrm{E}-2.4 .3$ & Реадн 220 мм \\
\hline & & & $2 \mathrm{E}-2.5$ & Окрема артилерійська бригада \\
\hline & & & $2 \mathrm{E}-2.8 .3$ & Артилерійський дивізіон 203 мм \\
\hline & & & 2E-2.8.2 & Артилерійський дивізіон 152 мм \\
\hline & \multirow{4}{*}{ 1E-2.2.4 } & \multirow{4}{*}{$\begin{array}{l}\text { Спроможність точно атакувати наземні і підземні } \\
\text { цілі на відстань до } 20 \text { км }\end{array}$} & 2E-2.7.1- 7 & БрАГ (омбр, опбр, отбр) \\
\hline & & & $2 \mathrm{E}-2.4 .2$ & Реадн 122 мм \\
\hline & & & $2 \mathrm{E}-2.8 .1$ & Артилерійський дивізіон 122 мм \\
\hline & & & $2 \mathrm{E}-2.8 .2$ & Артилерійський дивізіон 152 мм \\
\hline
\end{tabular}


3 урахуванням основного призначення PBiA, практичний розгляд фізичного змісту поняття “спроможності" доцільно здійснити на прикладі підгрупи спроможностей Вогневе ураження наземними засобами, Функиіональної групи № 5 Застосування, а за носій спроможності вибрати артилерійський дивізіон, як основний вогневий i тактичний підрозділ артилерії.
Безпосередній аналіз опису спроможності показує, що вона $\epsilon$ слабоформалізованою, не містить будь-яких кількісних або якісних показників (крім можливої дальності вогневого ураження, або автономності ведення бойових дій), iї неможливо описати точно за математичними методами (Табл. 2).

Опис вимог до спроможностей з вогневого ураження

\begin{tabular}{|c|c|}
\hline $\begin{array}{c}\text { Група/niдzрупа/код } \\
\text { спроможності }\end{array}$ & 1-Е2 Вогневе ураження/1-Е2.2 Вогневе ураження наземними засобами/1-Е2.2.4 \\
\hline 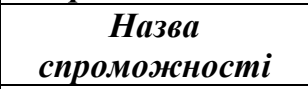 & $\begin{array}{l}\text { Спроможність точно атакувати наземні та підземні цілі, мінімізуючи супутній } \\
\text { збиток і жертви серед цивільного населення на відстань до } 20 \text { км }\end{array}$ \\
\hline $\begin{array}{l}\text { Базова вимога до } \\
\text { спроможнності }\end{array}$ & $\begin{array}{l}\text { 1.01. Спроможність надавати підтримку силам наземних операцій вогнем і } \\
\text { маневром, своєчасну, ефективну і рішучу вогневу підтримку з метою знищенн, } \\
\text { нейтралізації, придушення та дезорганізації сил противника }\end{array}$ \\
\hline $\begin{array}{l}\text { Основні вимоги до } \\
\text { спроможності }\end{array}$ & $\begin{array}{l}\text { 2.01. Спроможність комплексного захоплення/перехоплення цілей штатними та } \\
\text { нештатними засобами, інтегрованими у інформаційно-пошукову систему. } \\
\text { 2.02. Спроможність встановлювати зв'язок і координувати вогневу підтримку } \\
\text { приданих батарей/підрозділів. } \\
\text { 2.03. Спроможність швидкого залучення та виведення з бойових дій своїх сил }\end{array}$ \\
\hline $\begin{array}{l}\text { Додаткові вимоги } \\
\text { до спроможності }\end{array}$ & $\begin{array}{l}\text { 3.01. Спроможність діяти без підтримки або поповнення запасів протягом } \\
\text { щонайменше } 3 \text {-х діб. } \\
\text { 3.02. Спроможність вчасно надавати свіжі дані командуванню } 3 \text { проведення } \\
\text { операцій логістичного забезпечення щодо забезпечення МТЗ. } \\
\text { 3.03. Спроможність інтегрувати сили та засоби розвідки з метою підвищення } \\
\text { ефективності збору розвідданих }\end{array}$ \\
\hline
\end{tabular}

Водночас опис носія спроможності представлений кількісними і якісними показниками, які відповідають його бойовим можливостям (Табл. 3 ).

Опис вимог до носія спроможності з вогневого ураження

\begin{tabular}{|c|c|}
\hline $\begin{array}{c}\text { Група/код носія } \\
\text { спроможності/ } \\
\text { носій }\end{array}$ & 2-E2 Вогневе уражсення/2-E2.8.2/Артилерійський дивізіон 152 мм \\
\hline $\begin{array}{l}\text { Базова вимога до } \\
\text { носія } \\
\text { спроможності }\end{array}$ & $\begin{array}{l}\text { 1.01. Виявляти та уражати цілі, здійснювати маневр вогнем, силами і засобами, надавати } \\
\text { безпосередню вогневу підтримку загальновійськовим частинам (підрозділам) та виконувати } \\
\text { завдання з вогневого ураження противника на глибину 15-17 км }\end{array}$ \\
\hline $\begin{array}{l}\text { Основні вимоги } \\
\text { до носія } \\
\text { спроможності }\end{array}$ & $\begin{array}{l}\text { 2.01. Здійснювати вогневе ураження наземних елементів систем ВТЗ, артилерійських } \\
\text { (мінометних) батарей (взводів), підрозділів РСЗВ, ПТЗ, ПУ, танків, БМП та інших } \\
\text { броньованих об’єктів, ЖСіВЗ, засобів ППО, розвідки, РЕБ. } \\
\text { 2.02. Одночасно уражати до 3-х окремих цілей площею до } 6 \text { га, або групову ціль площею до } \\
16 \text { га, або ставити РЗВ на фронті до } 450 \text { м, або НЗВ на фронті до } 900 \text { м. } \\
\text { 2.03. Вести артилерійську розвідку штатними силами і засобами в інтересах вогневого } \\
\text { ураження противника на глибину до } 5 \text { км. } \\
\text { 2.04. Здійснювати переміщення різними способами вдень і вночі в будь-яких погодних } \\
\text { умовах та умовах місцевості своїм ходом до } 200-300 \text { км за добу }\end{array}$ \\
\hline $\begin{array}{l}\text { Додаткові } \\
\text { вимоги до носія } \\
\text { спроможності }\end{array}$ & $\begin{array}{l}\text { 3.01. Забезпечувати штатними засобами встановлений рівень захисту особового складу, } \\
\text { техніки та озброєння від вогневого ураження противника. } \\
\text { 3.02. Проводити тактичне маскування для забезпечення прихованості дій, введення } \\
\text { противника в оману та збереження боєздатності. } \\
\text { 3.03. Здійснювати технічне та тилове забезпечення з метою дій дивізіону без поповнення } \\
\text { запасів до } 3 \text {-х діб }\end{array}$ \\
\hline
\end{tabular}

Відповідно до [13] під бойовими можливостями військових частин (підрозділів) розуміють кількісно-якісну характеристику їх спроможності виконувати завдання щодо ураження противника ударами ракет і вогнем артилерії та здійснювати маневр у конкретних умовах обстановки. Бойові можливості характеризуються: вогневими та маневровими можливостями; можливостями щодо розвідки об'єктів противника.

Так, під спроможностями 3 вогневого ураження артилерійського дивізіону слід розуміти його здатність реалізувати свої бойові можливості для досягнення мети 
вогневого ураження в бою, використовуючи доктринально визначені форми i способи застосування з урахуванням:

умов обстановки, яка склалася;

стану готовності дивізіону до виконання завдань (укомплектованість особовим складом, стан підготовки особового складу, забезпеченість ОіВТ, забезпеченість МТ3);

кількості боєприпасів, які виділені на бій (часу, який виділяється для виконання вогневого завдання);

характеру цілей, які підлягатимуть ураженню з відповідним ступенем ураження.

Отже, такий самий підхід можливо застосовувати до визначення спроможностей 3 вогневого ураження i угруповань $\mathrm{PBiA} \mathrm{в}$ операціях угруповань військ (сил).

Переходячи до визначення поняття "розвиток" слід зазначити, що за різними джерелами $[10,14]$ це поняття визначається, як специфічний процес, унаслідок якого відбувається зміна якості чого-небудь, перехід від одного якісного стану до іншого, вищого.

Загалом "розвиток спроможностей" передбачає цілеспрямовану та послідовну зміну кількісних і якісних характеристик носія спроможності, яка призводить до набуття ним нової здатності щодо досягнення необхідного результату.

Згідно 3 [6] розвиток спроможностей здійснюється шляхом розвитку (вдосконалення) базових компонентів (складових) носіїв спроможностей.

Типовою $є$ ситуація, коли наявних спроможностей нинішніх організаційних структур буде недостатньо для реагування на майбутню воєнну загрозу (ефективність їх застосування буде нижче прийнятного рівня), тому і постає питання (вирішується завдання) щодо їх розвитку та (або) створення нових спроможностей.

Визначення недостатніх спроможностей Збройних Сил та інших складових сил оборони, які підлягають створенню, а також наявних спроможностей, які необхідно розвивати здійснюється в ході оборонного огляду під час планування сил за визначеними сценаріями (варіантами застосування) [15].

За поглядами $[16,17]$ на сучасному етапі найбільш перспективними напрямами підвищення спроможностей 3 вогневого ураження угруповань противника $\mathrm{PBiA} \epsilon$ подальше удосконалення:

систем озброєння 3 метою підвищення ефективності ураження об'єктів противника i відповідно всього угруповання загалом; організаційної структури військових частин (підрозділів) $\mathrm{PBiA} \mathrm{ЗС} \mathrm{України} \mathrm{для}$ максимальної реалізації їх потенційних можливостей у всьому можливому діапазоні умов ведення бойових дій, через застосування найбільш раціональних способів взаємодії між ними;

планування вогневого ураження 3 метою забезпечення максимально можливої реалізації потенційних можливостей сил i засобів РВіА ЗС України за допомогою їх раціонального розподілу по об'єктах противника.

Для більш точного визначення поняття "планування розвитку спроможностей PBiA ЗС України” наступним кроком надамо визначення саме поняттю "планування".

Відповідно до методу введення понять за ознакою “рід - вид" необхідно: по-перше, уточнити поняття “планування" як змісту діяльності з плануванням узагалі; по-друге, на основі добору суттєвих ознак такої діяльності визначити поняття "планування" i "планування розвитку спроможностей РВіА ЗС України”.

Будь-який процес управління складається 3 таких функцій: планування; організація; координація і регулювання; облік, контроль і аналіз; активізація і стимулювання. Функція планування - основа для прийняття управлінських рішень - управлінська діяльність, яка передбачає як вироблення цілей i задач управління будь-яким підприємством, так i визначення шляхів реалізації планів для досягнення поставлених цілей [18].

Отже, родовим для визначення поняття “планування" є поняття "управління". Зі свого боку, управління є певним видом діяльності та полягає у плануванні цієї діяльності та здійсненні управлінського впливу на об'єкт управління 3 приводу реалізації результатів планування. Так, поняття “діяльність", як гранично широку категорію [19], можна конкретизувати поняттям "діяльність щуодо розвитку спроможностей РВіА 3 Украйни”, а об'єкт управління впливу - поняттям “спроможності РВіА ЗС України”.

На основі аналізу вживання термінів “планування" і “план" у [10, 20], а також 3 урахуванням визначення поняття "планування" за [23], можна надати таке визначення: планування - це функція і етап управління, вид управлінської діяльності суб'єктів планування, змістом якого є: наукове передбачення майбутнього образу (стану) об'єкта управління (планування) прогнозування; визначення мети, системи 
цілей і завдань щодо приведення реального стану об'єкта планування до бажаного, а також засобів діяльності та упорядкування сукупності заходів щодо досягнення визначеної мети (цілей) - програмування; деталізація запрограмованої діяльності за виконавцями, термінами і засобами (ресурсами) - проєктування.

На основі цього визначення, яке характеризує родове поняття "планування", пропонується таке визначення: планування розвитку спроможностей РВіА ЗС України це вид управлінської діяльності суб'єктів планування у сфері оборонного планування, змістом якого $\epsilon$ наукове передбачення бажаного обрису PBiA ЗС України у майбутньому, відповідно до функцій і завдань, які покладені на PBiA 3С України у системі забезпечення обороноздатності держави, визначення мети, засобів і упорядкованої за часом, виконавцями i ресурсами системи заходів щодо досягнення визначеної мети, а також підготовки управлінських рішень у формі прогнозів, програм і планів у сфері оборонного планування.

Для забезпечення більшої наочності у визначенні поняття "планування розвитку спроможностей РВіА ЗС України" формалізуємо поняття "управління розвитком спроможностей РВіА ЗС Украӥни" у його системній інтерпретації. До того ж слід підкреслити, що у широкому розумінні сутність такого управління полягає у здійсненні сукупності заходів щодо усунення невідповідності реального стану РBiA i бажаного, тобто такого, який необхідно визначити, зважаючи на потреби задоволення воєнної безпеки держави 3 урахуванням іiі ресурсно-економічних можливостей. Іншими словами, йдеться про необхідність управитися з ситуацією зазначеної невідповідності.

Отже, процес управління розвитком спроможностей $\mathrm{PBiA}$ ЗС України можна розглядати як процес планування розвитку спроможностей $\mathrm{PBiA}$ ЗС України i процес реалізації результатів планування.

Висновки. 3 огляду на викладене, слід зазначити, що визначення поняття "планування розвитку спроможностей ракетних військ $i$ артилерї Збройних Сил України" створює теоретичні передумови для встановлення i вибору доцільних методів такого планування для ефективного визначення напрямів i шляхів розвитку спроможностей РВіА.

Крім того, відмінне від традиційного, більш широке тлумачення поняття планування є таким, що відповідає концепції планування, яка використовується у країнах-членах НАТО, а його розвиток і впровадження у практику $\epsilon$ одним iз напрямів удосконалення i підвищення ефективності планування i розвитку Збройних Сил України на основі спроможностей.

\section{СПИСОК ВИКОРИСТАНОЇ ЛІТЕРАТУРИ}

1. Про рішення Ради національної безпеки i оборони України від 20 травня 2016 року "Про Стратегічний оборонний бюлетень України” : Указ Президента України від 06.06.2016 р. № 240/2016.

2. Концепція комплексного вогневого ураження противника. Київ : ГШ ЗСУ, 2015.

3. Єдина загальновійськова методика оперативнотактичних розрахунків в ході планування вогневого ураження противника: навч. посібник. Київ : НУОУ, 2015. 212 с.

4. Рекомендації з оборонного планування на основі спроможностей в Міністерстві оборони України та Збройних Силах України : затв. Міністром оборони України 12.06.2017 p. URL: http://www.mil.gov.ua/ content/other/ Recommendationson_CBP_120617.pdf.

5. Ерышев А. А., Лукашевич Н. П., Сластенко Е. Ф. Логика : уч. пособ. 5-е изд., стереотип. Киев : МАУП, 2004. $216 \mathrm{c}$

6. Петров Ю. А., Захаров А. А. Практическая методология. Москва : МГУ, 2000. 107 с.

7. Барабаш Ю. Л. Основи теорії оцінювання ефективності складних систем. Методологія військово-наукових досліджень. Київ : НАОУ, $1999.39 \mathrm{c}$.

8. Manual for the Operation of the Capabilities Integration and Development System (JCIDS).\#3170/011/12 February 2015. Joint Staff, 2015. $416 \mathrm{p}$.

9. Joint Defense Capabilities Studies (Improving DOD Strategic Planning, Resourcing and Execution to SatisfyJoint Capabilities). Final Report, 2004. 128 p.

10. Великий тлумачний словник сучасної української мови. Київ : ВТФ, 2005. 1728 с.

11. Академічний тлумачний словник української мови. URL: http://sum.in.ua/.

12. Проект каталогу наявних спроможностей Міністерства оборони України, Збройних Сил України та інших складових сил оборони. Книга 1,2 .

13. Бойове застосування ракетних військ i артилерії в бою і операціях : підручник. Київ : НАОУ, 2010.

14. Украинский советский энциклопедический словарь. В 3-х т. / редкол.: А. В. Кудрицкий и др. Киев : Глав. ред. УСЭ, 1998. Т. 2. 768 с.

15. Методичні рекомендації 3 організації та проведення оборонного огляду в Міністерстві оборони України та Збройних Силах України : затв. Міністром оборони України 05.06.2019 р. 
16. Єдина загальновійськова методика оперативнотактичних розрахунків в ході планування вогневого ураження противника : навч. посіб. Київ : НУОУ, 2015. 212 с.

17. Оценка эффективности огневого поражения ударами ракет и огнем артиллерии. Военнотеоретический труд. Санкт-Петербург : $\mathrm{ABH}$, 2006. $422 \mathrm{c}$.

18. Воронкова В. Г., Катаев С. Л., Ткаченко А. М. Планування та прогнозування в умовах ринку : навч. посіб. / під ред. В. Г. Воронкової. Київ : Професіонал, 2006. 608 с.

19. Юдин Э. Г. Методология науки. Системность. Деятельность. Москва : Эдиториал УССР, 1997. $444 \mathrm{c}$.

20. Воронкова В. Г. Рабочая книга по прогнозированию. Москва : Мысль, 1982. 411 с.

21. Матвієнко В. Я. Прогностика. Київ : Українські пропілеї, 2000. 484 с.

Стаття надійшла до редакції 15.01.2020

\section{Planning of Development Capabilities of the Rocket Forces and Artillery of the Armed Forces of Ukraine:} understanding of the basis

\section{Annotation}

Analysis of regulations, practical implementation of measures during the implementation of defense planning based on Capability-Based Defense Planning System during 2019 revealed differences in the views of experts. They are mainly related to the lack of a unified vision of the conceptual apparatus and methodology for translating capabilities into quantitative and qualitative indicators for the transition of the Armed Forces of Ukraine and other components of Defense Forces to Capability-Based Planning.

The purpose of the article is to define the notion of "Planning development of capabilities of Rocket Forces and Artillery of the Armed Forces of Ukraine" (RFA).

Today as part of the Defense Review in Ukraine addresses the RFA development planning task based on the Capability-Based Planning procedures outlined in the Guidelines (methodical recommendations).

At the same time, an analysis of recent research shows that the content of RFA reform and development planning processes in previous years did not respond to its functions and as a result, the goals of RFA reform and development were not achieved.

An analysis of current conceptual papers on capability-based defense planning shows that researchers and experts have several points of view on the essence of the concept of "capability" and its relationship to such concepts as "capability" and "combat capability".

To provide greater visibility into the concept of "RFA Capability Development Planning", the concept of "RFA Capability Development Management" is formalized. The essence of such management is to implement a set of measures to eliminate the mismatch between the actual state of the RFA and the desired state. That is one that must be determined based on the needs of satisfying the military security of the state, considered it's a resource and economic capabilities. The RFA capability development management process can be considered as the RFA capability development planning process and the planning output implementation process.

Keywords: Management, Planning, Combat Capabilities, Rocket Forces and Artillery. 